\title{
Almuthasib - Considerações sobre o direito de almotaçaria nas cidades de Portugal e suas colônias
}

\author{
Magnus Roberto de Mello Pereira \\ Universidade Federal do Paraná \\ Colaboradores: Norton Frehse Nicolazzi Jr.* \\ e Mara Fabiana Barbosa ${ }^{\star *}$
}

\section{RESUMO}

A almotaçaria, uma das mais antigas e duradouras instituições das cidades de origem portuguesa, foi praticamente ignorada pela historiografia. 0 presente artigo tem por objetivo resgatar este tema. Procura demonstrar que as atribuições básicas do direito de almotaçaria (controle do mercado, do sanitário e do edificatório) revelam o núcleo profundo daquilo que era entendido como o urbano.

A ciência política tem proposto que o Estado moderno centralizado nasceu do aprofundamento e desdobramento da esfera administrativa do rei. Todavia, o estudo do direito de almotaçaria pode levar à conclusão de que este Estado de políticas públicas nasce pela apropriação das atribuições administrativas da cidade.

Palavras-chave: Direito de Almotaçaria; Portugal; Brasil colonial.

\section{ABSTRACT}

The almotaçaria, one of most long-term institutions of portuguese cities, was ignored by historiography for a long time. This article has by purpose to rescue almotaçaria as a historic theme. It wonders to demonstrate that three basic attributions of almotaçaria rights (market, sanitary and building controls) show the deepest meaning of the urban.

The science of politics has told that Modern State borns through advance and enlargement of King's administrative fields. However, the study of almotaçaria rights may drives to the conclusion that public policies state emerges from appropriation of county administrative attributions. Key-words: Almotaçaria rights; Portugal; colonial Brazil. 
O Arquivo da Câmara Municipal de Curitiba guarda uma vasta coleção de livros manuscritos que registram a ação dos almotacés da antiga vila de Nossa Senhora da Luz dos Pinhais. ${ }^{1}$ Esta documentação cobre, com algumas poucas lacunas, a atuação dos almotacés durante o período que vai de 1718 a 1828 . Ao contrário de outros livros municipais, como os de Atas da Câmara e de Provimentos dos Ouvidores, que foram criteriosamente transcritos e publicados por Francisco Negrão, os livros de Termos e Audiências dos Almotacés permaneceram inéditos e praticamente ignorados por parte dos historiadores. ${ }^{2}$

Isto não é de se estranhar, pois na historiografia brasileira há um preconceito solidamente estabelecido em relação à atuação administrativa das câmaras do período colonial. Abordar o tema dos almotacés nas nossas vilas e cidades coloniais é enfrentar este preconceito que, desde o século passado, aparece nos debates que foram travados sobre a importância ou não das câmaras municipais. A opinião de Capistrano de Abreu é exemplar a esse respeito.

A cada vez me convenço mais que João Francisco Lisboa falseou a história, dando-lhe uma importância que nunca possuíram as municipalidades. Só quando havia alvoroto, apareciam ligeiramente, em feições semelhantes às que os castelhanos chamavam cabildo abierto; fora disto, nomear almotacéis, aferir medidas, mandar consertar pontes, estradas e calçadas consumia-lhes todo o tempo. ${ }^{3}$

Todavia, "nomear almotacéis, aferir medidas, mandar consertar pontes, estradas e calçadas" talvez nos diga mais sobre a sociedade colonial luso-brasileira do que episódicos alvorotos valorizados por Capistrano. 0 exercício do direito de almotaçaria por parte das nossas câmaras municipais configuram aquilo a que denominamos de três agendas do viver urbano: a do mercado, a do construtivo e a do sanitário. ${ }^{4}$

Examinando os livros de registros desses oficiais camarários vamos perceber que sua atuação se concentrava, em primeiro lugar, no controle das relações de mercado. Em suas periódicas correições pela vila eles verificavam se todas as casas comerciais e oficinas de artesãos tinham a competente licença de funcionamento, se os pesos e medidas estavam corretamente aferidos e se o tabelamento imposto ao comércio era obedecido. Àqueles que infringissem os preceitos camarário: multas, discursos moralizantes e até mesmo prisão.

Aos Vinte e dois dias do mês de Julho de mil e Setecentos e quarenta e três nesta Vila de Nossa Senhora da luz dos Pinhais de Curitiba saiu de correição o Almotacel o Capitão Miguel Rodrigues Ribas pelas Ruas publicas desta Vila correndo todas as casas de vendas [...] e ofícios de Sapateiros e Alfaiates e condenou a Antunes Rodrigues dos Santos em um tostão por não ter tacha de seu oficio de Alfaiate 
e condenou também a Manoel Pereira Vidal em dez tostões a saber em cinco tostões de não ter registado dois escritos de aferição e em cinco tostões de não ter Almotaçado um pouco de toucinho e condenou também a Manoel Rodrigues Porto em seis tostões a saber em cinco tostões por não ter Almotaçado sal e em um testam por não ter taxa das obras de seu ofício de sapateiro e em cuja advertência tinha posto aos ditos oficiais por um edital que mandou passar o qual se publicou pelas Ruas desta Vila e assim mais condenou a Antônio Gomes e Setuvel em cinco tostões por não ter registado os escritos de aferições e assim mais condenou a Francisco da Cunha em seis tostões a saber em cinco tostões por não ter registado um escrito de aferição e em um tostão por não mostrar tacha do seu oficio de sapateiro e assim mais condenou a Frutuoso da Costa Braga em seis tostões a saber em cinco tostões por não ter registado dois escritos de aferições dos seis meses passados e em um tostão por não ter procurado da Câmara a tacha das obras de seu oficio de sapateiro e assim mais condenou a Francisco. Furtado em cinco tostões por não ter ainda a revista da petição de licença pelos os oficiais da Câmara dos seis meses últimos do ano e assim mais condenou a José Nunes [...] em cinco tostões por não ter almotaçado sal e bem assim achando-se o dito na casa do Concelho adonde esse dito Almotacel o mandou vir e aos mais sobreditos condenados para os exortar com seus ofícios e vendas publicas nesta Vila para viverem com elas e seus ofícios como Deus manda e a obrigação da Justiça para assim observarem falando o dito José Nunes na presença desse dito Almotacel o mandou meter na enxovia $[\ldots] .^{5}$

Antes de sair em correição, os almotacés apregoavam que os comerciantes deveriam ter "suas licenças preparadas e mais escritos de Almotaçarias e aferições cada um com suas portas varridas e asseadas e os tenham medidas prontas seus ramos verdes na porta com sua gamela e água e toalhas para se fazer [limpeza] nas medidas sendo necessário". ${ }^{6}$ Não hesitavam em condenar algum vendeiro "em Cinco tostões por não ter ramo verde" sobre a porta de seu estabelecimento, quando vendia bebidas alcoólicas. ${ }^{7}$ Um detalhe como esse diz respeito à persistência do caráter ibérico de nossas cidades, pois a exigência deste ramo indicativo já estava consignada na legislação das cidades medievais portuguesas.

Acharam por postura que os ramos que puserem nas portas das adegas não sejam de oliveira e ponham-nos tão altos nas portas que não possam os encavalgados a tangê-los com as mãos salvo se forem as adegas em tais ruas que não embarguem. Lisboa, $1314 .^{8}$

0 controle do abastecimento urbano por parte da municipalidade pode ser acompanhado através dos registros das multas aplicadas pelos almotacés curitibanos 
aos vendeiros locais, quando estes não obedeciam às taxas (tabelamentos) impostas pelo poder municipal. Ora era um comerciante punido "por vender Cinco Laranjas Ridículas que são as desta terra cinco ao vintém contra o Almotaçado", que era de 10 laranjas por vintém, ora era outro, "por este ter vendido uma quarta de farinha por uma pataca".

Ainda no que respeita às relações comerciais, ainda vamos encontrar os almotacés servindo de mediadores nos conflitos entre artesãos os consumidores de seus produtos e serviços.

Entrando da correição fez audiência, [...] e só apareceu Bonifácio Nunes e requereu ao dito Almotacel que Antônio de Araújo Miranda oficial de ourives o qual tinha em seu poder um anel para consertar, e como lho não tinha consertado requeria que viesse o dito Antônio de Araújo a sua presença para lhe entregar a dita obra ou feita ou na forma que se lhe tinha entregue e logo aparecendo o dito ourives perante o dito Almotacel e se consertou com o dito Bonifácio Nunes. ${ }^{10}$

Outra atribuição básica dos almotacés tinha por objeto a sanidade urbana. Uma parcela deste cuidado com o sanitário também dizia respeito aos estabelecimentos comerciais. Em suas periódicas correições pela vila os almotacés tinham o cuidado de verificar o estado de limpeza das ruas em frente aos estabelecimentos comerciais e artesanais. Não era incomum que os comerciantes fossem multados por não terem varrido as ruas. Note-se que nem todos colaboravam espontaneamente, é o caso de Bento Gonçalves, condenado "em Cinco tostões por lhe achar a porta suja escandalosamente com montes de bosta na sua porta mostrando fazer rebelião em não querer varrer". Mais raramente, este tipo de vigilância atingia o interior dos estabelecimentos, a exemplo da condenação imposta "a Manoel Gonçalves de Almeida em quinhentos Réis por este vender cachaça e não ter as medidas dela com o asseio costumado que deviam estar em uma gamela ou alguidar com água e cobertas [...] do pó e não como as tinha cada uma por sua banda secas e mal acondicionadas". ${ }^{11}$

Entretanto, a atuação dos almotacés em relação ao sanitário não se restringia a esse tipo de ação pontual. Era de sua responsabilidade a preservação das fontes de abastecimento de água potável. Coordenavam, ainda, a escavação de valos para o escoamento de água ou a dessecação dos charcos existentes no interior da vila ou em suas imediações.

Na mesma Correição foi apresentada a ele dito Almotacé uma petição dos moradores desta vila e habitadores em a rua que faz canto junto a Matriz cujos suplicantes se acham assinados em a mesma petição em a qual Reclamam que Sendo eles suplicantes obrigados a conservarem um canal por detrás dos seus muros pa- 
ra despejo das águas que no tempo delas alagam as mesmas Casas e Ruas por cujo motivo são estes obrigados a conservação do dito canal que para melhor definição determinou ele dito Almotacé que em correição se faria vistoria para se lhes deferir sobre o requerimento dos suplicantes e passando ele dito Almotacé comigo escrivão e Alcaide pela dita paragem achou que o sobredito canal que [...] os suplicantes beneficiavam em muita parte se acha fora dos muros dos suplicantes e com tal se acha o dito canal entupido; e por este motivo param as águas e ordinariamente no tempo delas se conserva um lago imundo de fronte das casas em que habita João de Abreu Guimarães ocasionando os inconvenientes que semelhantes lagos imundos costumam resultar, o tudo lhe pareceu a ele dito Almotacé resolver na forma do direito competente à sua jurisdição que. embargadas as obras dos canais e muros dos suplicantes propusessem estes todas as suas razões e suplicas aos oficiais da Câmara desta vila aos quais se fará remessa da sobredita petição dos suplicantes incorporando-se juntamente o teor desta resolução para eles ditos oficiais determinarem na conformidade do seu Regimento na certeza de que é sem disputa que o dito canal melhor e com mais limpeza se pode conservar dentro dos muros dos suplicantes ficando o mesmo canal correspondendo imediatamente para os lados de Leste ao Este para assim receber melhor o dito canal as águas que a este acudir de todos os canais particulares das ruas de cima para o que os suplicantes devem dar entrada para o recebimento em o seu canal mestre que ficava servindo de madre [...] das enxurradas e canos inferiores ficando assim todo aquele beco livre do dito lago e grande pantanal que continuamente sucede por falta do dito benefício; E por quanto Se acha aquele Beco que Corresponde aos muros dos suplicantes para a parte de Leste com sessenta e sete palmos de largura e para a parte do Este com cincoenta e três devendo-se por esta linha na retidão mais perpendicular tanto para a formalidade do aspeto público como para o cômodo do dito canal mestre para o que parece de Razão dar cômodo conveniente para que os suplicantes possam bem conservar o dito canal dentro dos seus muros ficando o dito beco na largura de quarenta e cinco palmos craveiros em linha reta sem denominação alguma parecendo a eles ditos oficiais da Câmara resolver assim ou como lhes parecer conforme seu regimento para o que o escrivão lançava este termo na petição dos suplicantes sendo-lhes como ele intimado para o recurso que devem ter sobre esta importante matéria tanto aos suplicantes como ao mais povo; e de como assim o determinou em correição mandou fazer este termo em que assinou com o Alcaide e eu Antônio Francisco Guimarães escrivão que o escrevi. ${ }^{12}$

Percebe-se que ao lado das preocupações com o sanitário, as medidas propostas pelo almotacé contemplam a própria configuração do traçado urbano da vila. Este tipo de ação caracteriza o terceiro viés do leque das atribuições da almotaçaria: a do construtivo. Nesta área, a atuação mais constante consistia em 
organizar a construção e manutenção de pontes, a pavimentação das ruas, e em multar os proprietários que não mantinham adequadamente os seus imóveis.

E correndo as Ruas achou ele S. Almotacel as casas da Senhora Isabel [...] com buracos da parte da rua e do quintal e mandou ao Alcaide que notificassem a dona das ditas casas para que em tempo de quinze dias as consertasse e na mesma forma mandou notificar a Antônio Soares e a José Leme para [...] para cada um consertarem suas casas em tempo de quinze dias por estarem as casas dos sobreditos desmontadas e com paus a pique [...]; e não consertando dentro dos ditos quinze dias serem condenados na forma dos capítulos da correição. ${ }^{13}$

Note-se que Curitiba não era nem uma cidade de porte médio para o padrão da época, muito menos um dos grandes pólos de comércio transatlântico, como o Rio de Janeiro ou Salvador, onde as questões do mercado, do saneamento ou do construtivo adquiriam uma complexidade muito maior. Mesmo assim, os almotacés curitibanos eram bastante atuantes nessas três esferas de competência. Isto não pode ser considerado como algo excepcional. Curitiba é exemplificativa das muitas pequenas vilas que se espalhavam pelo interior do território da América portuguesa. A documentação permite constatar que, no início do século XVIII, a atuação dos almotacés era um pouco frouxa, crescendo ao longo do século. 0 mesmo fenômeno foi constatado por Taunay em relação a São Paulo. "À medida que avançam os anos setecentistas se apuravam as demonstrações civilizadoras. Assim iam os almotacéis tomando importância que jamais haviam tido." ${ }^{14}$

\section{AL MUHTASIB}

À primeira vista, esses registros do exercício do direito de almotaçaria por parte das câmaras podem levar a uma leitura um tanto anedótica. Mais consistentemente, eles permitem acompanhar alguns aspectos da história econômica ou do viver cotidiano das vilas coloniais brasileiras. Todavia, o que se pretende propor é uma abordagem que resgate uma tradição administrativa específica em toda a sua complexidade. Não só em relação aos almotacés, mas às próprias câmaras municipais, uma vez que as abordagens que temos feito desta tradição estão excessivamente marcadas pelas leituras que fizeram os historiadores que nos precederam.

A historiografia clássica brasileira privilegiou a compreensão da cidade como instituição política, expondo com insistência a problemática do grau de autonomia das câmaras coloniais brasileiras em relação ao estado central português. Esta discussão foi herdada dos medievalistas portugueses do século XIX, 
em especial de Alexandre Herculano, a qual foi adaptada para se transformar em "questão colonial". Assim, o grau de autonomia da cidade medieval em relação ao rei tornou-se a nossa problemática da autonomia das câmaras coloniais em relação ao poder central da metrópole colonizadora. Hoje, mesmo em relação à história medieval, o sentido dessa questão da maior ou menor autonomia da cidade passou por diversas revisões, que não tiveram maiores impactos na historiografia brasileira, uma vez que esta se conformou com os antigos debates e não mais voltou ao tema.

É por demais sabido, como nos lembra Jacques Le Goff, que as pessoas da Baixa Idade Média "não pensavam, ao obter os forais, as franquias, em criar uma cidade". 0 que pretendiam era "formar uma comunidade capaz de fazer frente aos senhores". ${ }^{15}$ A luta por garantias políticas é um fenômeno que, a partir do século XII, atravessa todo o espaço europeu ocidental. Não apenas o citadino, mas o rural também. Portugal não foi exceção. Basta atentarmos para as muitas comunidades rurais do norte português que foram dotadas de forais: rudimentares e imperfeitos na classificação de Herculano, ou simplesmente rurais para Torquato Soares. ${ }^{16}$ Se não são franquias, nem as magistraturas eletivas que definem o urbano, como fazê-lo? Como a cidade toma consciência de si mesma?

Há, obviamente, uma consciência física fornecida pela aglomeração de edifícios. 0 urbano é uma interioridade, um sentido de separação com o exterior não-citadino, que as muralhas medievais ajudam a reforçar. Isto não é tudo, no entanto. Vive-se neste espaço, e para que isto seja possível alguém (todos, muitos ou poucos) precisa tomá-lo aos seus cuidados. Alguém precisa ser o responsável por veer a cidade. Administrá-la, no sentido mais lato. Se atentarmos para aquilo que é administrado, saberemos muito sobre o que é entendido como urbano num dado momento, sem a necessidade de recorrer a definições prévias.

$\mathrm{Na}$ cidade portuguesa da Baixa Idade Média, a definição do campo da ação administrativa tinha um nome muito preciso: almotaçaria. ${ }^{17}$ No norte da Europa, este campo precisou ser redefinido, podendo-se falar em uma invenção das instituições administrativas da cidade. Na península, entretanto, não houve uma completa descontinuidade urbana e muitas das instituições administrativas foram herdadas com a cidade islâmica. Herança não-estática, pois cidade e almotaçaria foram reformuladas pelos novos senhores cristãos. No entanto, especialmente em relação à almotaçaria, ao lado do processo de reelaboração existiram permanências, as quais, como veremos, inscrevem-se no sentido mais profundo do urbano.

Apesar de ser específica da cidade ibérica, a almotaçaria foi uma das instituições medievais menos estudadas pelos historiadores portugueses. Isto porque confundiu-se a pálida figura do almotacé da Idade Moderna com o instituto da almotaçaria, algo bastante mais amplo e complexo. Em geral, esquecem-se 
de um detalhe fundamental. Se, através da eleição de seus alvazis (juízes), os moradores da cidade medieval a apresentam na cena histórica como pólis, comunidade política dos cidadãos dotada de jurisdição e território, com a escolha dos almotacés ela se tornou urbe, comunidade administrativa autônoma.

A autonomia da administração urbana era algo completamente desconhecido na civilização muçulmana. Os oméias, califas de Bagdá, representam a passagem de uma confederação de guerreiros tribais nômades para um Estado imperial e centralizado. 0 império omíada deixara para trás os tempos do deserto e a administração passou a ser feita através de uma cadeia de cidades. No entanto, tais cidades estavam completamente submetidas à autoridade central, através de seus delegados regionais e locais. Os muçulmanos reproduziam muito das estruturas administrativas do império bizantino, do qual se haviam apossado da maior parte do território. Foram esses mesmos oméias, apoiados em exércitos de berberes convertidos ao islã, que empreenderam a conquista da península Ibérica, incluindo-a em seu Estado imperial.

Se tentássemos buscar as origens da instituição da almotaçaria seria fácil traçar a linha de filiação que vai do edil curul romano ao agoranome bizantino e ao muhtasib islâmico, depois cristão. Contudo, essas genealogias mais confundem do que esclarecem, pois, da mesma forma que os cristãos, os muçulmanos são herdeiros e continuadores das tradições greco-romanas. Basta-nos, desse modo, examinar o almotacé do ponto de vista da continuidade, ou não, entre as administrações das cidades pré e pós-reconquista.

Na cidade muçulmana, esse oficial era o responsável por uma de suas instituições urbanas características: a Hisba. Tal instituição tinha como missão a vigilância e aferição dos pesos e medidas; a eqüidade das transações comerciais; o controle dos diversos ofícios da cidade; a verificação do estado dos artigos de consumo alimentício; e a sanidade urbana. Era também responsável pela cidade sob o aspecto de entidade física. Cabia à hisba a reparação das muralhas, a manutenção das vias públicas e o controle das construções, de forma a evitar que estas ultrapassassem os limites dos lotes, apropriando-se terras públicas ou de vizinhos, ou que infringissem as normas construtivas vigentes, provocando um excessivo estreitamento ou ensombrecimento das ruas. ${ }^{18}$

Em árabe, o titular da Hisba era denominado Muhtasib. Quando o ofício foi incorporado, com algumas variações, nas diversas tradições municipais dos reinos da península Ibérica, o termo foi mantido: almotacé, em Portugal, almotacém, em Castela, e mustaçaf, nos reinos orientais da península e nas Baleares. Os reis cristãos não apenas mantiveram o cargo, após a reconquista, como a forma de provê-lo. Do mesmo modo que seus antecessores islâmicos, resguardaram para si a nomeação dos ocupantes, através de seus agentes locais, os alcaides, procurando manter o controle administrativo e econômico das cidades. ${ }^{19}$ 
Nos diversos reinos peninsulares, o processo de transformação do almotacé, de funcionário régio em oficial concelhio, não foi idêntico. Variou de reino para reino. Em Barcelona, por exemplo, ele só se concluiu no final do século XV. Mesmo nessa época, a escolha do mustaçaf era feita através de uma lista tríplice ou quádrupla apresentada pelos homens bons ao soberano de Aragão, a quem competia a escolha final.

No caso português, as câmaras de algumas cidades importantes obtiveram o privilégio de eleger os almotacés em período bastante mais recuado. 0 foral de 1179, dado por d. Afonso Henriques a Lisboa, Santarém e Coimbra, atribuía àqueles concelhos o poder de escolha desses oficiais. Posteriormente, muitos concelhos ao sul do Tejo receberam forais que consignavam o mesmo privilégio, tornando a eleição concelhia dos almotacés princípio generalizado. Isto ocorreu em algumas cidades que adotaram forais semelhantes ao de Coimbra, de 1111, e na generalidade das que tinham foros semelhantes aos de Ávila e Salamanca. ${ }^{20}$ Esta situação recobria parte da Beira, a Estremadura e o Alentejo. Mais tarde, com a conquista do Algarve, às cidades da região seriam dados forais semelhantes ao de Lisboa, o que as colocaria na mesma situação. Assim, do século XIII em diante, é mais ou menos padrão que o almotacé fosse um oficial de nomeação da municipalidade.

No entanto, a sua escolha foi, por muito tempo, compartilhada entre os concelhos e o alcaide, um delegado do poder régio. Esta prática aparece consignada nos forais e costumes de muitas cidades e vilas, como no caso dos costumes de Beja do século XIV.

Costume, que 0 alcaide e alvazis, e o concelho cada um mês façam seus almotacés, e ponham quais posturas quiserem e as tolham cada que quiserem, cada que é prol do concelho. ${ }^{21}$

Lembremos que essa região, onde a presença islâmica foi mais duradoura, era a porção do território português que concentrava os maiores núcleos urbanos, em oposição ao norte, onde prevalecia uma ocupação aldeã. Pode-se afirmar, por conseguinte, que na tradição urbana portuguesa, descontadas as primeiras décadas após a reconquista, a almotaçaria foi precocemente integrada na estrutura concelhia.

Mas isto também significou uma atrofia do cargo de almotacé, o qual progressivamente tornar-se-ia um oficial menor, de nomeação dos vereadores e a eles submetido. Muitas de suas atribuições acabariam migrando para a alçada dos próprios vereadores ou de outros oficiais municipais, ao contrário do que aconteceu no reino aragonês, exemplo que tomamos para contraste. Ali, o cargo 
de almotacé evoluiu para uma autêntica magistratura urbana, no mesmo nível dos juízes do cível e do crime.

\section{"DAS COUSAS QUE PERTENCEM"}

Em Portugal, o mais antigo regimento de almotaçaria que se conhece está inserido numa recompilação de posturas municipais de Lisboa dos séculos XIII e XIV. ${ }^{22} 0$ documento apresenta, logo em seu início, a definição do âmbito de competência dos almotacés. Percebe-se, de imediato, uma permanência das atribuições que lhes couberam no período islâmico. Se projetarmos para o futuro, veremos que algumas de suas atribuições chegariam intocadas ao século XIX. Apesar de ter variado quanto à forma de indicação, duração do mandato, ou mesmo por sua importância na estrutura de cargos administrativos das cidades, não podemos deixar de nos surpreender com essa espantosa continuidade de nome e função.

Na Lisboa do período, eram dois almotacés grandes, "um cavaleiro e o outro cidadão", ambos escolhidos pelo concelho, os quais, por sua vez, indicavam dois almotacés pequenos ou menores. Em qualquer dos casos, a duração do mandato era de um mês.

Das cousas que pertencem.

Em toda demanda que façam assim de parede como de portal que diz algum a outro que o não deve ali fazer ou que lha faz é no seu; ou sobre demanda que façam d'azevel* ou d'esterco ${ }^{\star *}$ ou sobre água verter ou sobre demanda de ruas e de frestas e d'azinhagas e de pardieiros ${ }^{* * *}$ e de janelas e de madeira por nas paredes e sobre fazer ou alçar casas e sobre enxurros e canos e sobre balcões ou sobre taboados fazer e sobre feitos das ruas e das carreiras e das calçadas fazer e sobre monturos e as fontes limpar e resguardar e adubar ${ }^{* * * *}$ e outrossim sobre vinho de fora pôr e sobre todas as coisas compradas que forem para vender todas estas cousas sobreditas fazem e pertencem à Almotaçaria. ${ }^{23}$

Apenas a seguir aparece a competência pela qual estamos habituados a identificar os almotacés, a de fiscal dos pesos e medidas.

Os Almotacés grandes e pequenos em sembra ${ }^{*}$ [e] cada um por si devem ser tidos de ver e guardar os pesos e as medidas por que vendem e compram também nas casas como nas adegas como nos outros lugares onde quer em tal maneira que sejam todos direitos e iguais a todos comunalmente também para os estranhos como para os da vila e as medidas e os pesos que acharem falsos quebrantá-losão e devem levar os Almotacés de qualquer falsidade para a almotaçaria da pri- 
meira vez 5 soldos e na segunda 5 e na terceira vez que aí for achado seja homem quer mulher devem-no por no pelourinho e pague de lá suso ${ }^{* \star} 5$ soldos ou lhe farão como mandar o Concelho se algum seu degredo passar que seja por ele posto. ${ }^{24}$

Há que perceber uma ruptura na redação entre os dois segmentos. Seguramente não saíram de uma mesma pena e não são de uma mesma época. Arriscar-se-ia a afirmar que o primeiro trecho, pela colocação invertida do verbo, foi redigido originalmente em latim e depois traduzido, um tanto literalmente, para o português. Já a segunda parte, que confere ao almotacé a competência de fiscal de pesos e medidas, obedece à forma-padrão dos degredos ou posturas, em que estão incluídas, inclusive, as penalidades aos infratores. Pode-se imaginar que, de fato, a competência original dos almotacés lisboetas está definida no primeiro segmento, no qual a preocupação com o urbano e o construtivo é acentuada. A suspeita é corroborada pela fórmula de encerramento, "todas essas cousas sobreditas que fazem e pertencem à almotaçaria".

Percebe-se que a ênfase da competência original do almotacé recai sobre o construtivo e o sanitário. No restante, ela ficava restrita a "sobre vinho de fora pôr e sobre todas as coisas compradas que forem para vender", de onde deriva a responsabilidade sobre pesos e medidas. Na seqüência, o documento entra no âmbito característico das posturas municipais, desdobrando a competência do almotacé em algumas normas de controle urbano.

É de se notar a semelhança deste regimento com seus congêneres do restante do mundo hispânico. 0 original do documento a que nos referimos não mais existe em Portugal, e só nos é permitido conhecer o seu teor devido a uma cópia bastante antiga encontrada num arquivo de Navarra. Presume-se que essa cópia tenha servido de subsídio à elaboração de outros regimentos de almotaçaria. Nos reinos peninsulares, não era incomum que um município adotasse forais, regimentos ou posturas de outros, independentemente das fronteiras nacionais, ainda em formação.

Ao analisar as mustaçafias do sudeste da península, o historiador espanhol Sevillano Colom percebeu que os diversos municípios da região tomaram como exemplo os regimentos de Valência. No que respeita às edificações, os mustaçfs estavam encarregados de resolver questões relativas às "servidões de paredes medianeiras, abertura de janelas, etc.," em perfeita consonância com o que ocorria em Portugal. ${ }^{25}$ Tal ordem de atribuições não era, portanto, uma peculiaridade da almotaçaria de Lisboa, ou de alguns municípios portugueses. Neste aspecto, parece haver uma homogeneidade peninsular, herdada de um passado islâmico comum das cidades dos novos reinos cristãos.

As atribuições dos almotacés de Lisboa aparecem muito mais desenvolvi- 
das num regimento de $1444 .{ }^{26}$ Todavia, neste documento a definição das esferas de competência não é mais do que uma cópia do regimento anterior. 0 que se altera é o corpo de posturas que o acompanha, em que as questões urbanas aparecem muito mais esmiuçadas. Não podemos, porém, concluir que o desenvolvimento que a questão urbana sofre neste diploma seja exatamente deste período ou redigido em Lisboa. Nada nos garante que não temos em mãos uma recompilação de posturas mais antigas, ou cópia da legislação de outra localidade, apenas reiterada por esse diploma. É o que nos sugere a comparação com regimentos de outros países da península onde é possível encontrar os mesmos desdobramentos da competência dos almotacés em períodos bastante mais recuados, e que consignam medidas idênticas às adotadas em Portugal.

As atribuições básicas dos almotacés foram mantidas em todas as colônias portuguesas, bem como o termo pelo qual eram designados. ${ }^{27} 0$ regimento dos almotacés foi incorporado, modernizada a sua redação, às Ordenações Manuelinas. Assim, o seu alcance atingiu o conjunto do universo urbano português da Europa e das colônias. Mantiveram-se, também, as atribuições originais dos almotacés: o controle do mercado, do sanitário e do construtivo.

Neste ponto, a historiografia portuguesa mais recente costuma cometer um equívoco. Enquanto alguns historiadores - como Marcelo Caetano ou o próprio Herculano - chamaram a atenção para o amplo leque de atribuições urbanísticas dos almotacés, outros, de gerações mais recentes, costumam apresentá-las como competências adquiridas tardiamente através das Ordenações Manuelinas, principalmente aquelas voltadas ao processo edificatório.$^{28}$ É o que afirmam Banha de Andrade, em sua monografia sobre Montemor-o-Novo, ou António Manuel Hespanha, em sua História das Instituições. ${ }^{29}$

Tal engano é compreensível, uma vez que as Ordenações Manuelinas (século XVI) delegam algumas atribuições aos almotacés que não constavam das Afonsinas (século XV), o que levou à suposição de que fossem uma novidade. No entanto, elas não são mais do que redação modernizada dos antigos regimentos dos almotacés de Lisboa.

Os ditos almotacés conhecerão de todas as demandas, que se fazem sobre o fazer, e o não fazer de paredes de casas, ou quintais, e assim de portais, janelas, frestas ou eirados, ou tomar ou não tomar d'águas de casas, ou sobre meter traves, ou qualquer outras madeiras nas paredes, ou sobre estercos e sujidades, ou águas, que se lançam como não devem, e sobre canos e enxurros, e sobre fazer de calçadas, e ruas. ${ }^{30}$

Na realidade, o que se observa nas Ordenações Manuelinas em relação aos almotacés é a junção de duas tradições legislativas. A primeira, mais antiga, é 
esta que acabamos de traçar, a qual aparece de forma acabada no Regimento de Lisboa. A outra é aquela resultante da lenta codificação das atribuições dos diversos oficiais concelhios, contida nos Regimentos de Oficiais, elaborados a partir da segunda metade do século XIV. Um bom exemplo destes regimentos é aquele dado a Évora, em tempos de d. João I, o rei que deu início ao processo de codificação que levaria às Afonsinas. ${ }^{31}$ Este mesmo regimento está contido nas próprias Ordenações Afonsinas e no Regimento dos Oficiais do Reino impresso por Valentim Fernandes em 1504, por ordem de d. Manuel. ${ }^{32}$ Nestes textos, os almotacés recebem diversas atribuições em relação ao mercado e à limpeza urbana, no entanto, no que respeita ao construtivo há uma completa omissão, que será superada com a inclusão das atribuições previstas nos regimentos de Lisboa. Feita esta fusão, não aconteceriam alterações de monta, pois as Ordenações Filipinas apenas repetem 0 anteriormente disposto. ${ }^{33}$

Note-se que as duas últimas ordenações continuam atribuindo aos almotacés o papel de resolver "demandas”. Mas há uma diferença substancial entre o papel de mediador que os almotacés ocupavam em períodos mais recuados e 0 de polícia das normas municipais que, progressivamente, foram assumindo. Tal mudança corresponde à passagem do direito consuetudinário, no qual prevalecia a força do costume, para o direito positivo, determinado pelas normas legais escritas, no caso as posturas municipais.

\section{CORPORA, COMMUNITATES}

O instituto da almotaçaria expressa com perfeição as instituições políticoadministrativas da Baixa Idade Média. A almotaçaria portuguesa tomou forma durante um período que, comumente, tem sido denominado de corporativo, ou de sistema político corporativo, ou ainda, mais abrangentemente, de sociedade corporativa. Este período tem sido examinado como o de uma sociedade que emerge de uma "crise feudal", mas que não é ainda uma sociedade moderna.

Trata-se de mais um destes tantos buracos negros das periodizações, que costumamos esconder sob o conceito teleológico de períodos de "transição". Com transição queremos dizer que, no exame a posteriori que nos é permitido fazer do período, encontramos algumas coisas que identificamos como restos de um passado mais remoto, e outras que consideramos pertencer à gênese da nossa sociedade contemporânea. 0 instituto da almotaçaria atravessa a última Idade Média e se estende por todo este período de múltiplas 'transições' que, conforme o ângulo de observação, chamamos de Idade Moderna, Antigo Regime ou Mercantilismo. Ela pertence a um período para o qual não existe nome, 
algo que estaria entre o não-Estado e o Estado, entre o não-mercado e o mercado, entre a não-cidade e a cidade.

Do ponto de vista das instituições, a almotaçaria pertence a uma época em que o poder político era representado como "articulação (hierarquizada) de múltiplos círculos autônomos de poder (corpora, communitates) — as famílias, as cidades, as corporações, os senhorios, os reinos, o Império" ${ }^{34} \mathrm{~A}$ escolástica medieval foi a principal responsável por forjar a imagem da sociedade como um grande corpo, que é o resultado do funcionamento harmônico de seus corpos componentes (intermediários e menores), cada um deles dotado de uma autonomia limitada pelo funcionamento do todo. Estes corpos componentes, integrados por um conjunto de homens (corporação, cidade, etc.), equiparam-se aos órgãos de um ser vivo. São necessariamente desiguais entre si, dotados de finalidades próprias, irredutíveis uns aos outros, mas indispensáveis ao funcionamento geral. A cabeça, responsável pela harmonia entre as partes, é identificada com o rei, o centro desta ordem. Trata-se de uma concepção hierárquica de sociedade, na qual não há, portanto, a menor pretensão a uma igualdade. Porém, ela trabalha com um sentido de anti-individualismo, de pertinência a um todo coerente, e de estabilidade das coisas. Todos têm o seu lugar e todos têm direito a viver. Mas cada um segundo o seu estado, e a cada um segundo o seu estado.

Nesta ordem, os órgãos menores são concebidos como miniaturas do grande corpo. Devem encontrar uma harmonia interna entre as partes que o integram e com a cabeça real. E a cidade também tem a sua cabeça, representada pelos concelhos, comunas, ou câmaras, além de diversos corpos menores: clero, fidalgos, cidadãos, corporações de ofício, ou as próprias famílias que a habitam. 0 modelo proposto pela escolástica medieval afirmava que a administração do reino e da cidade eram diferentes escalas de uma mesma coisa, uma concepção ainda hoje aceita. 0 que dizem as atuais teorias sobre o Estado e as instituições?

António Manuel Hespanha caracteriza a administração régia do período como "passiva", exercício de um poder mediador que agia apenas para reconstituir a ordem quando se instauravam conflitos entre os corpos constituintes do reino. Para ele, o poder administrativo da cidade se manifesta de maneira semelhante à ação do rei.

Isto é verdadeiro em relação aos poderes das cidades cujo governo visa, antes de tudo, à consecução da paz urbana, apesar de as circunstâncias da vida em comum de grande número de famílias criarem problemas novos - relativos ao abastecimento, à saúde, ao urbanismo - que as cidades têm que resolver. ${ }^{35}$

Note-se que Hespanha, apesar de tomar o partido da semelhança entre as 
práticas administrativas do rei e da cidade, abre caminho para a constatação da diferença. Mesmo não se debruçando sobre o tema da almotaçaria, ele escolhe as suas atribuições básicas (mercado, sanitário e construtivo) para caracterizar os problemas advindos do viver em cidade que, a nosso ver, dão o recorte preciso da ação da almotaçaria. Contudo, ele nos deixa em suspenso. Quais são as conseqüências institucionais advindas deste tripé de dificuldades que não se configuram como a administração passiva do rei, que nem é idêntica à administração econômica privada (no sentido grego de prover as necessidades dos membros da casa - oikos).

A fim de evitar este problema é preciso introduzir uma separação entre as noções de pólis e de urbe. Para que não seja um recorte arbitrário, vamos tentar esclarecer esta separação. A pólis, tal como a entendemos, é a identidade política da cidade, a esfera de delimitação de seus direitos e deveres com o rei e dos direitos e deveres entre os 'corpos' que a compõem. Já a urbes é o lugar da prática de harmonização interna entre as partes constituintes da cidade e da administração ativa do oikos urbano. Prática que não competia ao rei nem aos corpos menores, mas um dos direitos da cidade: o direito de almotaçaria. Os reis preferiam representar esse direito de almotaçaria como um direito adquirido através de doação régia. Já as cidades costumavam postulá-lo como direito radicado, costume imemorial do qual estavam em posse.

A almotaçaria é, simplesmente, a prática cotidiana deste direito, a administração da cidade. A diferença entre a administração do rei e a da cidade reside exatamente neste ponto. Enquanto a administração do rei era eminentemente passiva (poder mediador e judiciário), a da cidade era tanto passiva, pois também exercia o poder de mediar, quanto ativa, uma vez que os concelhos administravam uma "economia". A longa história da formação do Estado ocidental centralizado coincide com a apropriação desta esfera de administração ativa pelos reis. A cidade, a quem pertencia tal esfera, vai resistir durante muito tempo, encarando a ampliação dos poderes régios como usurpação dos seus. Colocado desta maneira, podemos concluir que o Estado nacional moderno não nasceu, portanto, de aprofundamentos e desdobramentos da esfera administrativa do rei, mas pela apropriação da esfera administrativa da cidade. 0 direito de almotaçaria e suas práticas correspondentes forneceram o modelo sobre o qual formou-se o Estado administrativo centralizado.

Este direito de almotaçaria da cidade medieval ibérica apoiava-se na noção de "preço justo", que lhe fornecia a chave do controle de todas as atividades comerciais e artesanais da cidade. 0 conceito também passou pela elaboração doutrinária tomística. Na imagem escolástica da sociedade, cada corpo, além de ter um lugar próprio, tinha um valor absoluto e outro relativo, razoável ou proporcionado $($ relação = razão = proporção). 0 valor razoável, diga-se, preço ra- 
zoável ou justo, deveria ser fixado de acordo com as estações do ano, a produtividade da terra, a distância entre produtor e consumidor, sem se ater aos interesses de grupos ou indivíduos. ${ }^{36}$

Esta noção de que o mercado deveria ser pautado por uma moralidade, na busca do preço justo, define muitas das práticas de almotaçaria que se destinavam a garantir a qualidade da produção, impedir fraudes, tabelar preços, evitar monopólios e intermediações que encarecessem os produtos, estabelecer acordos com fornecedores ou mesmo racionar alimentos, quando necessário. Racionamento desigual e proporcional à condição de cada um, obviamente. É bom lembrar que, no universo de origem portuguesa, onde se inclui o Brasil, todas essas práticas estavam amplamente disseminadas, como pudemos observar em relação aos almotacés de Curitiba, e adentraram o século XIX.

No que respeita ao construtivo, cabia à almotaçaria conduzir as obras feitas em "comum benefício", assim como mantê-las. Também se incluía, neste direito geral da cidade, mediar os conflitos provocados pelas construções, de modo a garantir a paz. Da mesma forma, o acesso à terra urbana deveria ser pautado por princípios morais. Enquanto este poder não sucumbiu às pressões da especulação imobiliária (que se manifestou muito cedo), a terra urbana costumava ser doada a quem fosse aceito como vizinho (o morador da cidade). Não seria dado novo lote a quem possuísse outro sem construir. As casas abandonadas e arruinadas podiam ser doadas a quem quisesse ocupá-las. Isto subsistiu por longo tempo nas localidades menores de Portugal. Na maior parte do Brasil, a concessão de cartas de data (de doação da terra urbana) foi uma realidade até a primeira metade do século XIX.

O sanitário, sempre tão negligenciado pelos estudiosos, também integrava, como já apontamos, o direito e a ação da almotaçaria. Era atribuição básica da cidade garantir a própria existência da vida em seu interior, assegurando o acesso ao alimento e ao abrigo, mas também mantendo o estado de saúde dos moradores. Não se tratava de prover uma medicina ativa (curativa), mas de manter um estado de equilíbrio (profilaxia) que permitisse à vida prosperar num ambiente que muito cedo se demonstrou nefasto.

Para o modelo tomista, a saúde corpórea não se diferenciava da saúde moral. Os males que afligiam o corpo da cidade eram causados pelo desequilíbrio entre suas partes ou pela má circulação dos humores entre elas. As doenças morais eram provocadas pela falência de alguns órgãos ou pelo agigantamento de certas porções em detrimento de outras. A exemplo de qualquer mortal, as cidades eram atingidas por males físicos, tão ou mais mortais que os males morais. 0 excesso ou a estagnação dos humores urbanos faziam o corpo da cidade apodrecer. Era preciso, portanto, mantê-los em boa circulação.

Esse modelo era um ideal de harmonia a ser atingido. Na cidade real, o que 
não faltou foram os desequilíbrios responsáveis pelas doenças físicas e morais. Todos sabemos que as instituições da cidade foram apropriadas em benefício de certos grupos ou indivíduos. Mesmo assim, ela forneceu aos seus moradores uma sensação de pertencimento a uma ordem urbana estável, que se apoiava nestas noções de moral e equilíbrio expressas no direito de almotaçaria.

Acompanhando as três principais agendas do viver urbano nas cidades de origem portuguesa (a da forma, a do podre e a do mercado) observa-se que, em todos os casos, houve uma trajetória comum. Num primeiro momento, as práticas administrativas se expressavam na ação mediadora dos almotacés, provocada por conflitos vicinais que, depois, foram substituídas por normas de direito escrito (as posturas municipais). ${ }^{37}$ Por último, o Estado centralizado foi-se apropriando dessas agendas urbanas. A tal apropriação das práticas administrativas das cidades corresponde a emergência das modernas ciências iluministas do saneamento, do urbanismo e da poderosíssima economia política.

Na passagem entre os séculos XVIII e XIX ensaiava-se a constituição de um Estado centralizado em políticas públicas. Porém, em seu período inicial, esse Estado ainda não estava muito aparelhado para ações mais concretas e se limitava mais a fazer diagnósticos do que a implementar suas políticas. As ciências que dariam suporte a essas políticas apenas estavam engatinhando. Eram ainda pretensões que se revelavam mais como obsessões pelas coisas pútridas, pela regularidade da forma urbana ou pelo livre mercado, do que por sua eficácia e aceitação geral. Assim, os agentes do Estado central (administradores, engenheiros, arquitetos, naturalistas, economistas) passariam a ser cheiradores eméritos. Não houve poço, cloaca, casebre que não fosse vasculhado pelos narizes atentos dos agentes do Estado central e minuciosamente descritos. Da mesma forma, o construtivo foi submetido a uma mania da ordem geométrica, e as relações de mercado às insistentes pregações de que a ordem econômica era auto-regulável.

Entendemos que essas políticas do Estado não se tratavam exatamente de invenções. Eram apenas atualizações de certos temas inerentes ao viver em cidade (as agendas do viver urbano) que, como estamos procurando demonstrar, estavam expressas nos antigos regimentos de almotaçaria. Chegando ao século XVIII, percebe-se que a almotaçaria ainda demonstra vitalidade, tanto em Portugal como nas colônias. Mais surpreendente, durante a primeira metade do século XIX, as câmaras do Brasil Império ou do Portugal do liberalismo valiam-se constantemente do direito de almotaçaria, nos mesmos moldes do que vinha ocorrendo há séculos. Estamos, portanto, diante de uma instituição que, pelo menos no papel, atravessou os séculos. 
Esta espantosa continuidade do desenho institucional da almotaçaria portuguesa cria alguns problemas sobre sua localização no interior das teorias sobre o Estado. Para a Ciência Política, durante o século XVIII teria ocorrido a superação do Estado 'tradicional'. Ao príncipe deixara de caber a garantia da harmonia dos diversos corpos sociais (ordens, corporações), ação que ia sendo substituída pelo moderno Estado administrativo. Esta nova situação é caracterizada tanto por uma mudança quantitativa - 0 aumento das tarefas assumidas pelo Estado - , quanto qualitativa, que corresponde ao trânsito de uma arte de governar para uma ciência de governo. ${ }^{38}$

A passagem da política — como arte do governo, ou seja, da pura ação política segundo os ditames da razão de Estado - à polícia - como ciência de governo, ou seja, da ação administrativa segundo as funções e os fins próprios do Estado - é, sem dúvida, de grande importância. É óbvio que a polícia não se substitui à política, antes continua sempre subordinada às suas exigências supremas e insuprimíveis. Mas o desenvolvimento destas doutrinas que se propõem determinar as formas e os métodos da atividade ordinária e normal dos governos, em correlação com os fins do Estado, é a expressão de uma nova mentalidade de tipo claramente iluminista. ${ }^{39}$

Em Portugal, não há dúvidas de que o período pombalino representa esta passagem. Os insucessos de boa parte das políticas propostas pelo despotismo iluminado pombalino não eliminam o fato. Note-se que estamos falando de políticas. Até agora procurei evitar o uso da noção para não incorrer em anacronismo. Apenas no século XVIII difunde-se entre os próprios agentes históricos envolvidos com tarefas de Estado a noção de polícia (as nossas modernas políticas públicas).

A centralização dos poderes de Estado propõe-nos duas questões. A primeira, de âmbito mais geral, é indagar sobre o lugar que a antiga concepção de administrar a cidade, expressa no direito de almotaçaria, ocupou na definição das esferas e formas de atuação do Estado centralizado que emergiu no século XVIII. A segunda, é saber como, ou com que intensidade as políticas superaram a almotaçaria no universo português. Trata-se, portanto, de investigar, em ambos os casos, a relação existente entre a polícia (as políticas públicas) e a almotaçaria.

AS POLÍTICAS E A ALMOTAÇARIA

O maior campo de lutas entre almotaçaria e a economia política foi o do mercado de abastecimento urbano. Como era de se esperar, Lisboa foi a cidade 
que sofreu com mais força o impacto da centralização. Desde 1572, a cidade era governada por letrados de nomeação régia. ${ }^{40}$ Todavia, tendo por pretexto o terremoto que a atingiu, Pombal promoveria um completo esvaziamento dos poderes deste concelho já tão dependente das decisões do rei. ${ }^{41}$ Durante a reconstrução, a Coroa apropriou-se dos direitos que a cidade detinha sobre o processo edificatório, numa escala que ultrapassava a área destruída. Embora soubesse impossível, Manuel da Maia, o arquiteto-mor da reconstrução, sonhava com a renovação completa da cidade. ${ }^{42} \mathrm{~A}$ pretensão de criar uma nova Lisboa foi assumida pelo Estado central, que se encarregou de garantir diretamente, e não através da Câmara, "que as Ruas da mesma Cidade, e os edifícios, que nela se erigirem, sejam reguladas e conservadas com a polícia, que se faz tão recomendável em comum benefício". ${ }^{43}$

No que concerne ao construtivo, a Câmara de Lisboa teve o seu poder de almotaçaria completamente esvaziado. Ainda que Eugênio dos Santos, um dos arquitetos do Senado de Lisboa, recebesse a incumbência de desenhar os novos prédios padronizados, ele foi cada vez mais um arquiteto do Estado central e menos da municipalidade. Em alguns momentos, esta exclusão do poder municipal torna-se explícita. Um alvará de Pombal proibia qualquer interferência da Câmara nas obras da Alfândega e da Praça do Comércio, que estavam a cargo da Junta do Comércio. ${ }^{44}$

Esta Junta do Comércio do Reino e seus Domínios foi a instituição do Estado central criada para assumir as atribuições da almotaçaria relativas ao comércio. Pelos seus estatutos, ela deveria ser responsável pela política comercial e artesanal de todo o império. Na prática, a sua atuação não foi muito além de Lisboa, onde estabeleceu uma concorrência direta com o poder de almotaçaria do Senado, a Câmara da capital do Império. Senado e Junta travaram uma batalha de décadas sobre a competência de conceder licenças para o funcionamento de oficinas e de examinar os mestres de ofício. Em relação a alguns ramos artesanais, a Câmara perdeu o poder decisório e tornou-se uma instância intermediária, obrigada a referendar automaticamente as decisão tomadas pela Junta. Outro espaço de disputa foi o poder de inspeção sobre o comércio. A Junta tentaria tomar esta competência para si e isentar as lojas de Lisboa das inspeções dos almotacés. ${ }^{45}$

0 desabastecimento provocado pelo grande terremoto foi a justificativa para o Estado central desencadear um processo de desregulamentação do mercado de víveres, subtraindo-o do poder de almotaçaria da Câmara. Um alvará de 21 de fevereiro de 1765 determinava que os vendedores "possam livremente vender pelos preços que ajustarem com o comprador" ${ }^{46}$ Apenas o pão, 0 azeite e a palha ficaram fora deste livre mercado. Todavia, esta última foi objeto de um extenso regulamento promulgado pela administração pombalina. ${ }^{47} \mathrm{~A}$ cidade dei- 
xou de ser a responsável pela provisão de palha para tornar-se a executora de uma política definida pelo Estado central. Afinal, o novo papel do município deveria ser o de agência local de um Estado cada vez mais centralizado. Mas, em que medida este quadro ideal realizou-se ou ficou restrito a Lisboa?

No Brasil, embora freqüentes opiniões em contrário, predomina a idéia de que, no século XVIII, o Estado central português assume um domínio quase completo sobre as Câmaras. ${ }^{48}$ Em Portugal, onde o tema foi estudado mais detalhadamente, variam muito as opiniões sobre a interferência do poder central. Maior ou menor, o que tem sido detectado é a perda do poder político das cidade. No entanto, este esvaziamento político não foi, necessariamente, acompanhado da perda do poder de administrar. Muitas vezes, os mesmos autores que advogam a total dependência das Câmaras em relação ao Estado central, quando passam a estudar a atuação de alguma Câmara específica, deparam-se com este campo quase imutável da administração local.

Um dos principais advogados da tese da centralização precoce do Estado português foi Alexandre de Lucena e Vale. ${ }^{49}$ Entretanto, em seus estudos sobre Viseu no século XVIII, ele nos apresenta uma Câmara em pleno uso de seus poderes de almotaçaria. ${ }^{50}$ Sérgio Cunha Soares, outro autor que tomou Viseu como objeto, é categórico em afirmar que há um absoluto contraste entre Viseu e Lisboa no que diz respeito ao exercício dos poderes administrativos. ${ }^{51} \mathrm{Em}$ seu estudo sobre a Câmara de Portimão, Luís Vidigal verificou que as taxas de almotaçaria (tabelamento de preços) continuaram em vigor até $1834 .^{52} \mathrm{Um}$ tabelamento que fora legalmente extinto na década anterior. Apenas no Porto é possível detectar uma tendência contrária. Quando das reformas urbanas pombalinas, a cidade perdeu uma parcela de sua competência sobre o construtivo. Todavia, esta é apenas mais uma exceção.

Nas colônias, as principais exceções foram as sedes das capitanias, Estados e vice-reinos. Os funcionários ilustrados costumavam conduzir algumas políticas gerais para a sua área de jurisdição e outras específicas para as suas capitais. De fato, a ingerência política ou administrativa nessas capitais foi grande. Mas em relação aos outros lugares, ela era drasticamente menor. Através dos exemplos anteriormente apresentados relativos à Câmara de Curitiba, pode-se verificar não apenas a permanência do exercício do direito de almotaçaria, mas o seu crescimento ao longo do settecento. ${ }^{53}$

Curitiba é representativa de uma grande parcela das localidades brasileiras, para as quais o século XVIII foi um período de relativo crescimento urbano. Se nos séculos anteriores a ênfase de muitas Câmaras recaía sobre a mediação política, no XVIII ela passou a concentrar-se sobre a mediação administrativa. ${ }^{54}$ Não podemos, no entanto, imaginar que isto as tornava lugares de uma proto-administração iluminista, pois o que ocorria era um reforço 
ou a retomada dos velhos princípios da almotaçaria. Essas Câmaras coloniais ainda eram corpos de representação dos cidadãos, que se reuniam para conduzir discussões delimitadas pelo secular regimento dos almotacés. Idealmente, a sua ação continuava a ser pautada por uma noção de mercado moral, regulado pela idéia do justo preço, e pela defesa de uma ordem espacial e sanitária, que se apoiava na tradição. É interessante perceber que, em muitos casos, foram os próprios agentes do Estado central português os responsáveis por insistir junto às Câmaras que o papel delas era exatamente este. Para Curitiba e outras localidades de jurisdição da capitania de São Paulo, as correições do ouvidor Rafael Pires Pardinho, realizadas no início da década de 1720, são muito elucidativas a este respeito. ${ }^{55}$

No século XIX não ocorreram alterações bruscas. Apenas muito lentamente seria permitido às Câmaras organizarem-se a modo e semelhança de um Estado central em miniatura, como no caso do Brasil, e um pouco menos do que isso em Portugal e nas colônias africanas, quando estas se tornaram independentes.

Durante muito tempo, conviveram o Estado centralizado iluminista e uma organização municipal ainda apegada a suas prerrogativas tradicionais. Conhecemos muito melhor este Estado central do que as administrações locais, pelo simples fato de que há uma notável diferença entre as respectivas capacidades discursivas. Era da natureza da nova arte ou ciência da administração (polícia) produzir um grande número de estudos, análises, relatórios e estatísticas. Nela, os homens de letras ocuparam um papel cada vez maior. Já a antiga administração apoiava-se mais em práticas do que em produzir discursos sobre elas. As suas falas eram esparsas e fragmentárias, até porque não havia a necessidade de justificar ações que se apoiavam numa tradição antiqüíssima.

Esta discrepância é muito visível quando comparamos o novo sanitarismo do século XVIII com as antigas práticas adotadas pelas Câmaras. 0 mesmo ocorre em relação ao mercado livre. Há um discurso-padrão sobre as vantagens do livre comércio que se reproduz na documentação do Estado e na produção acadêmica da época. Desde Pombal, o Estado português é declaradamente "antifeudal". Uma das instituições mais lembradas como "feudais", pelos autores setecentistas, é justamente o direito de almotaçaria. Basta ver os muitos artigos publicados nas Memórias Econômicas da Academia Real das Ciências de Lisboa, nos quais as posturas e tabelamentos de preços são acusados de "atacar os princípios da Economia Política". ${ }^{56}$

0 longo preâmbulo do código de posturas da cidade açoriana de Angra, de 1788, foi uma das raras respostas sistematizadas aos defensores da economia política. É quase um libelo contra os ataques à ordem tradicional. Não por aca- 
so, a elite camarária da cidade inicia explicando o seu papel, atribuindo o seu poder a uma origem quase divina.

Moisés, o mesmo Moisés, cujos sentimentos eram divinos, pela familiaridade que tinha com Deus, elegeu de entre o Povo Israelítico, varões fortes e tementes do Altíssimo, para governarem e proverem as necessidades do Povo, reservando para si as decisões mais graves, e de mais alta indagação. ${ }^{57}$

Trata-se de uma total reação escolástica aos novos discursos. A Câmara de Angra contrapõe-se frontalmente à razão iluminista de mercado, propugnando a continuidade de uma ação pautada pelo conceito medieval de razoável. As leis deveriam adaptar-se aos novos tempos, mas "a ordem geral deve ter suas exceções, conforme as sociedades e segundo os lugares, onde as mesmas coisas não têm sempre um igual valor". Séculos depois ainda ecoavam certos princípios propostos por São Tomás de Aquino e seus seguidores. Após a longa exposição tomista, entra-se finalmente num completo código de posturas, no qual aparece vigorosa toda a tradição da almotaçaria. 0 código fecha com uma tabela geral de preços da produção artesanal. Neste momento, a legislação geral do reino já impunha o livre comércio da maioria dos gêneros, mesmo assim os vereadores de Angra proíbem que couro, sumagre, tremoços e linhaça sejam "extraídos" da área de jurisdição do concelho.

A postura sobre a comercialização de couros é demonstrativa daqueles entraves postos pelas Câmaras à livre circulação de mercadorias. Contudo, ela também demonstra a noção de ordem moral à qual deveriam estar sujeitas as operações comerciais.

Que nenhuma pessoa compre couros para embarcar da terra para fora enquanto forem necessários para os sapateiros fornecerem suas tendas em beneficio do povo, e aos lavradores para uso e serviço de suas lavouras: com a pena de seis mil reis; e no caso de haver sobras recorrerão à Câmara para depois de ter examinado o surtimento do povo, lhe conferir as licenças para a extração com as necessárias Fianças..$^{58}$

Angra não foi uma exceção. Este tipo de prática continuava generalizada por todo o Império..$^{59} \mathrm{~A}$ maioria das Câmaras simplesmente adotava posturas deste tipo sem se dar ao trabalho de justificá-las, outras o faziam em nome dos novos tempos. Não podemos esquecer que muitas medidas adotadas pelo Estado central padeciam da mesma ambigüidade. 0 mercado regulamentado era tão generalizado que o próprio discurso iluminista via-se obrigado a reconhecê-lo.

Quase por toda parte as Posturas, que dirigem o comércio intrínseco, são outros 
tantos embaraços que se opõe ao seu giro. [....] Observe-se o que estas posturas impedem, além das que já se lembraram contra a livre exportação dos vinhos, proíbem outras, que se tirem para fora do termo rezes, pão, vinho, azeite, legumes, qualquer mantimento em geral, caça, galinhas, lenha, carvão, junco, palha, e cevada, e até mesmo pedras, sem que estas paguem ao concelho 60 réis por carreta. [....] A comodidade de haver abundância, e bom preço em razão destas proibições, que antigamente se supunha, e a rivalidade feudal das terras umas para as outras, é a causa destas posturas, quase gerais por todo reino. Hoje conhecemos bem, que o consumo, e exportação é que faz a abundância, e que desta é que vem o bom preço, pois a carestia segue necessariamente a falta do gênero, que o cultivador despreza, quando não há de ter mais que o preciso para comer. ${ }^{60}$

Esta situação pode ser explicada pelo fato de a economia portuguesa ter permanecido eminentemente agrária.$^{61}$ Nos advertiu o economista Karl Polanyi, que nos países onde a economia industrial se impôs mais cedo, as elites agrárias usaram o seu poder político na defesa de uma organização mais tradicional. Desta maneira, elas deram tempo para que a sociedade se ajustasse aos novos padrões de mercado, contendo em níveis menos intoleráveis a desagregação social que estes provocavam. ${ }^{62}$ Se é verdadeiro que nesses países há uma continuidade das antigas práticas regulatórias, mais ainda o é no universo lusitano. 0 que se verifica, tanto em Portugal quanto nas colônias, é uma permanência dos antigos "corpos" que, embora cada vez mais relegados a uma situação periférica, continuaram a exercitar a velha ordem.

A força com que isto se manifesta nas Câmaras não nos deve levar a concluir que a elite agrária concelhia detinha o monopólio destes valores. Eles estavam profundamente radicados na população em geral. Quase todos os movimentos e revoltas populares, além de outros nem tão populares, se autodefiniam como conservadores ou restauradores. Sua ação era pautada pelo retorno a uma ordem perdida. ${ }^{63}$ Muitas vezes, as revoltas iniciavam-se com clamores por pão. ${ }^{64}$ No entanto, esta alegação de fome não se referia apenas à fome real provocada por um mau ano agrícola. A fome era sintoma de um desequilíbrio moral, uma ruptura do pacto da almotaçaria. 0 grito contra a fome, quase sempre real, pois ela era endêmica, dava partida a lutas contra a apropriação de alimentos escassos pelos poderosos, mas também contra excesso de impostos, usurpação da terra, do poder local ou da própria Coroa.

Segundo o historiador inglês E. P. Thompson, os estudiosos que procuram criar um vínculo direto e imediato entre os motins populares do século XVIII e a fome cometem uma simplificação grosseira. Thompson soube perceber que, nesses movimentos de massa, a ação se apoiava num sentido de legitimidade, 
ou seja, que os envolvidos acreditavam estar defendendo direitos e costumes tradicionais.

Isto estava [....] baseado em uma idéia tradicional das normas e obrigações sociais, das funções econômicas próprias dos distintos setores da comunidade que, tomadas em conjunto, pode dizer-se que constituem "a economia moral dos pobres". ${ }^{65}$

Se no século XVIII isto é verdadeiro para a Inglaterra e outros países que lideraram a revolução industrial, mais verdadeiro é para Portugal e colônias. 0 sentimento de perda de uma antiga ordem estável estava presente em diversas revoltas nas quais se envolveram as corporações dos artesãos, seja em Salvador (1710), seja em Angra (1757) ou no Porto (1757). As congregações das corporações de ofícios, denominadas como Casas dos Vinte e Quatro ou Casa dos Doze, entraram nestas lutas visando a repor uma moralidade perdida; no Porto, a do mercado do vinho; em Angra, a do trigo; e em Salvador, a do sal. ${ }^{66}$ Estas lutas, centradas numa expectativa de mercado justo, adentraram o século XIX; vejase o movimento dos quebra-quilos, provocado pela introdução do sistema métrico no Brasil.

Das três vertentes constitutivas da almotaçaria, aquela que expressava a justiça de mercado foi a que demonstrou um maior apelo popular. Todavia, as regulamentações de mercado encontraram na Economia Política um inimigo de peso, que se dedicou a suprimi-las como prática e como valor.

As do saneamento e do construtivo foram, por séculos, encaradas como normatividade externa. Mas os seu efeitos foram mais duráveis e hoje integram valores normalmente aceitos. 0 pútrido e a forma ainda permanecem na esfera da administração local. Isto porque as políticas iluministas interagiram de forma muito diferente com cada ramo da almotaçaria. As ciências específicas do salubrismo e do urbanismo retomaram o caráter normativo destas posturas e 0 aprofundaram. A "cidade liberal”, produzida apenas por macropolíticas que concediam ao livre mercado um poder auto-regulador sobre a produção do tecido urbano, demonstrou-se rapidamente inviável. ${ }^{67}$ Assim, mesmo numa época em que os Estados centrais de Portugal e do Brasil eram declaradamente livre-cambistas, continuou aberto o campo das lutas travadas em torno de instituições medievais como a almotaçaria e as posturas municipais.

\section{LA LONGUE DURÉE}

0 exercício do direito de almotaçaria, consubstanciado nas posturas sobre questões sanitárias e sobre produção do espaço, é apenas uma pequena parcela 
das normas legais que acompanham o longo processo do fazer-se citadino. São fragmentos que, ao lado de muitas centenas de outras posturas, se acumularam, ao longo dos séculos, em camadas estratigráficas nos livros de registros. Cada uma dessas posturas tem uma longa história. Passaram por diversos processos de revisão e foram confirmadas, modificadas, revogadas ou simplesmente esquecidas. São sobrevivências do direito consuetudinário medieval, refletem a produção teórica do Renascimento. Nasceram de acalorados debates entre vereadores, negociadas com as corporações de ofícios, impostas pelo rei, pelo capitão, pelo corregedor ou pelo ouvidor. Quem sabe foram copiadas da cidade vizinha? Ou de outro continente $?^{68}$ No entanto, ao lado de todas estas variações, encontramos novamente um fundo de permanências. Jamais saíram do quadro proposto pelos regimentos medievais de almotaçaria.

Como já vimos, esses regimentos atribuíam aos almotacés três ordens de competência. A primeira, sobre "água verter", "azevel” e "esterco", é característica da questão sanitária. Outra, sobre portais, paredes e balcões, remete aos aspectos construtivos e formais da cidade. Por fim, a superintendência das "coisas compradas que forem para vender" coloca as relações de mercado no centro da questão urbana. Em conjunto, elas configuram as principais agendas do viver urbano.

Considerando que as Ordenações Filipinas continuavam em pleno vigor no Brasil até o início do século XIX, temos em mãos uma instituição mais do que milenar, mesmo descontados os seus antecedentes pré-islâmicos. Apenas no reino cristão de Portugal foram mais de 700 anos, em que se mantiveram o nome e a instituição. Ao longo desses séculos, os almotacés perdem o exclusivo dessa tríade de competência para os outros oficiais da cidade. 0 concelho, o município, a Câmara ou a Prefeitura passaram a ser depositárias do direito de almotaçaria, compartilhando-o com os crescentes poderes do Estado centralizado.

Paramos por aqui para não nos aproximarmos perigosamente da atualidade. Entretanto, será que alguém teria dúvidas de que os atuais códigos de posturas das grandes cidades, cheios de tecnicismos, continuam tratando de "demandas de ruas e de frestas e d'azinhagas e de pardieiros e de janelas", "sobre monturos e as fontes limpar" ou sobre "alçar casas"? E que, ainda hoje, "todas estas cousas sobreditas fazem e pertencem à Almotaçaria"?

Fenômeno estructurale?, inscrito numa longue durée? Enveredando por uma especulação braudeliana, diríamos que esta reunião de funções aparentemente desconexas na figura do almotacé revela um núcleo profundo e permanente daquilo que era entendido como o urbano. A almotaçaria expressa uma consciência específica de cidade (o urbano): trama em que estão inextrincavelmente reunidos o sanitário, o construtivo e as relações de mercado. Por sua vez, esta consciência desemboca nas três principais agendas do viver urbano: a do po- 
dre, a da forma e a do mercado. Versão urbanizada de uma leitura triádica dos perigos do mundo, aos quais a cidade deve dar respostas, que corresponde aproximadamente aos mais temidos flagelos medievais: a peste, a guerra e a fome.

\section{NOTAS}

* Mestrando dos Cursos de Pós-graduação em História da UFPR, integrante do CEDOPE - Centro de Documentação e Pesquisa - Paraná - Século XVIII. Na qualidade de bolsista PROLICEM da UFPR, participou do levantamento e transcrição da documentação setecentista do Arquivo da Câmara Municipal de Curitiba.

** Acadêmica do Curso de História da UFPR, integrante do CEDOPE - Centro de Documentação e Pesquisa - Paraná - Século XVIII. Na qualidade de bolsista PIBIC/CNPQ, participou do levantamento e transcrição da documentação setecentista do Arquivo da Câmara Municipal de Curitiba.

${ }^{1}$ CARDOSO, Jaime Antonio. "Arquivo da Câmara Municipal de Curitiba". In Boletim do Departamento de História da Universidade Federal do Paraná. Curitiba, 1968, n.6, pp.14 e 24 .

${ }^{2}$ Curitiba é uma das raras cidades brasileiras a contar com um acervo expressivo de 390 documentação municipal do período colonial. Mais raro ainda, parte significativa desta documentação está transcrita e impressa na publicação Boletim do Archivo Municipal de Curitiba.

${ }^{3}$ ABREU, Capistrano de. Correspondência. Rio de Janeiro : INL, 1954, v.2, p.28.

${ }^{4}$ A questão aparece mais desenvolvida em PEREIRA, Magnus Roberto de Mello. A forma e o podre; duas agendas da cidade de origem portuguesa nas idades medieval e moderna. Curitiba: UFPR, 1998. (Tese de doutoramento defendida nos Cursos de Pós-graduação em História da Universidade Federal do Paraná sob a orientação da prof ${ }^{a}$. dr. ${ }^{\text {a }}$ Ana Maria de Oliveira Burmester).

${ }^{5}$ CURITIBA. Câmara Municipal. Audiências dos Almotacéis. 1737-1749, f.29. Doravante os Livros de Termos de Audiências e Aferições dos Almotacés de Curitiba serão referenciados como TAAAC.

${ }^{6}$ TAAAC, $1737-1749$, f.25.

${ }^{7}$ TAAAC, 1755-1757, f.4.

${ }^{8}$ POSTURAS DO CONCELHO DE LISBOA, (sec. XIV), Lisboa: Sociedade de Língua Portuguesa, 1974, p.53.

${ }^{9}$ TAAAC, 1755-1757, ff. 4 e 40.

${ }^{10}$ TAAAC, $1737-1749$, f.47.

${ }^{11}$ TAAAC, 1755-1757, f.4, e TAAAC, 1737-1749, f.57 v.

${ }^{12}$ TAAAC, 1766-1800, ff.30v-31v. 
${ }^{13}$ TAAAC, 1737-1749, f.16v.

${ }^{14}$ TAUNAY, Affonso de E. “História da cidade de São Paulo no século XVIII”. 1701-1711. Annais do Museu Paulista, São Paulo, 1931, tomo 5, p.401.

${ }^{15}$ LE GOFF, Jacques. O apogeu da cidade medieval. São Paulo: Martins Fontes, 1992, p.5.

${ }^{16}$ SOARES, Torquato Brochado de Souza. Apontamentos para o estudo das origens das instituições municipais portuguesas. Lisboa: s.ed., 1931.

${ }^{17}$ A palavra almotaçaria foi usada, desde a Idade Média, tanto em sentido geral, para designar a instituição ou suas atribuições, quanto em sentido particular, para designar as atividades mais correntes do almotacé e, depois, da câmara em relação ao abastecimento das cidades. Almotaçar era fiscalizar o comércio, ou garantir que todos pudessem encontrar alimentos no mercado, impondo racionamento quando preciso, ou, ainda, tabelar preços. Neste último sentido, que chegou ao século XIX, a almotaçaria era qualquer tabelamento de preços, mesmo os que não tinham eram de responsabilidade das municipalidades. Ver, por exemplo, o famoso tabelamento geral dos preços do reino, de autoria de d. Afonso III. LEI DE ALMOTAÇARIA; 26 de dezembro de 1253, $2^{\text {a }}$ ed. Lisboa: Banco Pinto \& Sotto Mayor, 1984.

${ }^{18}$ SEVILLANO COLOM, Francisco. "De la institución del mustaçaf de Barcelona, de Majjorca y de Valencia”. In Anuário de História del Derecho Español. Madrid, 1953, t.23, p.527.

${ }^{19}$ CAETANO, Marcelo. A administração municipal de Lisboa durante a primeira dinastia. 1179-1383. Lisboa: Livros Horizonte. 1991, pp.16-7. SEVILLANO COLOM, op. cit., pp.530-2.

${ }^{20}$ SOARES, Sérgio Cunha. "Os vereadores da Universidade na Câmara de Coimbra, 16401777”. In Revista Portuguesa de História, Coimbra, tomo 26, 1991, p.101.

${ }^{21}$ COLECÇÃO DE LIVROS INÉDITOS DA HISTÓRIA DE PORTUGAL, v.4, p.527. Citado de LANGHANS, Franz-Paul. As posturas. Lisboa: Faculdade de Direito da Universidade de Lisboa, 1937, p.22.

${ }^{22}$ POSTURAS DO CONCELHO DE LISBOA, op. cit.

${ }^{23}$ POSTURAS DO CONCELHO DE LISBOA, op. cit., p.45.

* Azavel ou Azevel = lixo, porcaria em árabe ou hebraico.

$\star \star$ Esterco $=$ fezes.

$* * \star$ Pardieiro $=$ Edificação em ruínas, do latim paredenarium.

$\star * * *$ Adubar $=$ aumentar, incrementar.

${ }^{24}$ POSTURAS DO CONCELHO DE LISBOA, op. cit., pp.45-6.

$\star$ Em sembra $=$ conjuntamente.

* Suso = debaixo, sob.

${ }^{25}$ SEVILLANO COLOM, op. cit., pp.536-7. Não tive a oportunidade de consultar diretamente os documentos originais, ou mesmo as suas transcrições, citados pelo historia- 
dor. Todavia, por tudo que ele menciona, tem-se a certeza de que ele tinha em mãos regulamentos em tudo semelhantes aos portugueses.

${ }^{26}$ LIVRO DAS POSTURAS ANTIGAS. Lisboa: Câmara Municipal, 1979, pp.98-113.

${ }^{27}$ No Brasil, o nome só foi latinizado no século XIX, quando o termo foi substituído por fiscal. No universo colonial castelhano, o quadro era mais complexo. Em alguns municípios parece não haver oficiais que reunissem as atribuições clássicas dos almotacés, em outros eles eram denominados diputados. Ver, por exemplo, as Ordenanzas del Cabildo de Quito transcritas no apêndice documental de DOMINGUEZ COMPAÑY, Francisco. La vida em las pequeñas ciudades hispanoamericanas de la conquista. Madrid: Ediciones Cultura Hispanica, 1978.

${ }^{28}$ HERCULANO, Alexandre. História de Portugal desde o começo da monarquia até o fim do reinado de Afonso III. Lisboa: Bertrand, s.d. 8.ed. v.7, pp.320-1. CAETANO, op. cit., p.16.

${ }^{29}$ ANDRADE, António Alberto Banha de. "Montemor-o-Novo, vila regalenga"; ensaio de história da administração local. Primeira parte: 0 poder político dos reis e a administração do concelho durante os séculos XIII-XVI. In Cadernos de História, Montemor-oNovo, 1976, n.2, pp.33-4.

HESPANHA, António Manuel. História das instituições; épocas medieval e moderna. Coimbra: Livraria Almedina, 1982, pp.249-50.

$392{ }^{30}$ ORDENAÇÕES MANUELINAS, livro I, título 49, § 33.

${ }^{31}$ Ver transcrição em PEREIRA, Gabriel Vítor do Monte. Documentos históricos da cidade de Évora. Fascículo I, Foros e costumes ou direito consuetudinário municipal nos séculos XII e XIII. Évora: Typographia da Casa Pia, 1885, pp.164-7.

${ }^{32}$ Ver ORDENAÇÕES AFONSINAS e REGIMENTO DOS OFICIAIS DAS CIDADES, VILAS E LUGARES DESTES REINOS. Lisboa: Fundação Casa de Bragança, 1955 (fac-símile da edição original de 1504).

${ }^{33}$ ORDENAÇÕES FILIPINAS, livro I, título 68, § 22.

${ }^{34}$ HESPANHA, História das instituições, p.66.

${ }^{35}$ HESPANHA, História das instituições, p.67.

${ }^{36}$ Num tempo e lugar específicos as coisas tinham um valor razoável, mantidas as condições. Ver HESPANHA, História das instituições, pp.196-7.

${ }^{37}$ Sobre a legislação municipal ver PEREIRA, Magnus R. M. e SANTOS, Antonio C. A. "Códigos de Posturas Municipais". In Monumenta. Curitiba, Aos Quatro Ventos, inverno 1998, v.1, n.3, pp.1-22.

${ }^{38} \mathrm{Não}$ pretendo enfrentar a árdua questão das políticas de Estado, ou do Estado de políticas. Em língua portuguesa, uma boa síntese sobre a questão é HESPANHA, António Manuel. Poder e instituições na Europa do antigo regime. Lisboa: Fundação Calouste Gulbenkian, 1984.

${ }^{39}$ HESPANHA. Poder e instituições, p.266. 
${ }^{40}$ OLIVEIRA, Eduardo Freire de. Elementos para a história do Município de Lisboa. Lisboa: Typographia Universal, 1887, t.1, pp.7-33.

${ }^{41}$ A obra que melhor sistematiza este esvaziamento é de SOARES, Sérgio Cunha. "Aspectos da política municipal pombalina”; a Câmara de Viseu no reinado de d. José. In Revista Portuguesa de História, Coimbra, 1985, tomo 21.

${ }^{42}$ FRANÇA, José Augusto. Lisboa pombalina e o iluminismo. Lisboa: Livros Horizonte, 1965, p.86.

${ }^{43}$ PORTUGAL. Alvará de 15 de junho de 1758. Collecção de Leis, Decretos e Alvarás, que comprehende o feliz reinado del Rei Fidelissimo D. José o I. Lisboa: Officina de Antonio Rodrigues Galhardo, 1797. tomo 1, 1750-60, s.p.

${ }^{44}$ Ver OLIVEIRA, op. cit., tomo 16, p.340.

${ }^{45}$ Idem, pp.306-13. SOARES, Aspectos, pp.24-6.

${ }^{46}$ OLIVEIRA, op. cit., tomo 17, pp.24-7. SOARES. Idem, p.33.

${ }^{47}$ PORTUGAL. Alvará de $1^{\circ}$ de julho de 1752. Collecção de Leis,. tomo 1, s.p.

${ }^{48}$ ZENHA, Edmundo. O município no Brasil; 1532-1700. São Paulo: Ipê, 1948, pp. 16572. PRADO JR., Caio. Evolução política do Brasil e outros estudos. São Paulo: Brasiliense, 1953, p.41.

${ }^{49}$ VALE, Alexandre de Lucena e. "História e Municipalidade; novos conspectos." Anais da Academia Portuguesa de História, v.16.

${ }^{50}$ VALE, Alexandre de Lucena e. Viseu do século XVIII nos livros de actas da câmara. Viseu: Junta Distrital, 1962.

${ }^{51}$ SOARES. Aspectos, p.37 e seguintes.

${ }^{52}$ VIDIGAL, Luís. Câmara, nobreza e povo; poder e sociedade em Vila Nova de Portimão. 1755-1834. Portimão: Câmara Municipal, 1993, p.126.

${ }^{53}$ Sobre a permanência de valores como o de "preço justo" e de maneiras de agenciar o espaço, ver PEREIRA, Magnus R. M. Semeando iras rumo ao progresso. Curitiba: Editora da UFPR, 1996, p.28 e seguintes.

${ }^{54} \mathrm{O}$ aumento destas atividades administrativas levou Janice Theodoro da Silva a concluir que, no século XVIII, aumentou a "autonomia" da Câmara de São Paulo em relação ao Estado central. SILVA, Janice Theodoro da. São Paulo 1554-1880; discurso ideológico e organização espacial. São Paulo: Editora Moderna, 1984, p.109.

${ }^{55}$ MARCONDES, Moysés. Documentos para a história do Paraná. Rio de Janeiro: Typographia do Annuario do Brasil, s.d. NEGRÃO, Francisco. (ed.) Boletim do Arhivo Municipal de Curitiba, v.1, n.1.

${ }^{56}$ OLIVEIRA, Joaquim Pedro Gomes de. "Extracto das Posturas da Villa de Azeitão." Memmorias Economicas da Academia Real das Sciencias de Lisboa. Lisboa, t.3. 1791, p.307. Ver também, no mesmo periódico: NOGUEIRA, António Henrique. "Racional discurso sobre a agricultura, e população da Província do Alentejo.” , t.1, 1787. 
PORTUGAL, Thomaz António Villa Nova. "Memória sobre a preferência que entre nós merece o estabelecimento dos mercados ao uso das feiras de anno para o commercio intrínseco". , t.2, 1790 .

${ }^{57}$ RIBEIRO, Luís da Silva. "Posturas da Câmara Municipal de Angra em 1788". In Obras. tomo II - História. Angra do Heroísmo: Instituto Histórico da Ilha Terceira, 1983, p.415.

${ }^{58}$ RIBEIRO, op. cit., p. 147.

${ }^{59}$ Oliveira Marques considera espantosamente tardia a sobrevivência dos mercados locais regulamentados e auto-suficientes em Portugal. MARQUES, A. H. de Oliveira. Introdução à história da agricultura em Portugal. Lisboa: Cosmos, 1978, pp.117-21.

${ }^{60}$ OLIVEIRA, Extracto, pp.316-7.

${ }^{61}$ Alguns autores consideram que, na Europa como um todo, a supremacia da economia agrária e da nobreza fundiária a ela vinculada é um fenômeno que se estende até a Primeira Grande Guerra. Em decorrência, estendem a baliza cronológica do Ancien Régime até 1914. Ver, por exemplo, MAYER, Arno J. A força da tradição; a persistência do Antigo Regime. São Paulo: Cia. das Letras, 1987.

${ }^{62}$ POLANYI, Karl. A grande transformação; as origens da nossa época. Rio de Janeiro: Editora Campus, 1980, p.169.

${ }^{63} \mathrm{Em}$ muitos levantamentos populares, acreditou-se estar restaurando o bom governo

394 do rei, que era enganado por prepostos e emissários responsáveis pelo mau governo. Ver OLIVEIRA, António de. Poder e oposição política em Portugal no período filipino. (1580-1640). Lisboa: Difel, 1990, pp.191-2.

${ }^{64}$ Isto foi freqüente nas diversas revoltas antitributárias seiscentistas contra 0 aumento do cabeção de sisas, ou a imposição do real d'água e do papel selado. Ver MAGAHÃES, Joaquim Romero. "1637, os motins da fome.” BIBLOS, Coimbra, 1976, tomo 3. OLIVEIRA, António de. "Levantamentos populares no arcebispado de Braga em 1635-1637." Bracara Augusta, v.34, n.91, jan.-dez.1980, pp.419-46.

${ }^{65}$ THOMPSON, E. P. Tradición, revuelta y consciencia de clase; estudios sobre la crisis de la sociedad preindustrial. Barcelona: Editorial Crítica, 1979, pp.64-6.

${ }^{66}$ RUY, Affonso. História da Câmara Municipal da cidade do Salvador. Salvador: Câmara Municipal, 1953, pp.173-87. SILVA, Francisco Ribeiro. "Os motins do Porto em 1757"; novas perspectivas. In POMBAL REVISITADO. Lisboa: Editorial Estampa, 1984, pp.24783. DRUMMOND, Francisco Ferreira. (ed.) Annaes da Ilha Terceira. Angra do Heroísmo: Câmara Municipal, 1856, v.2, pp.269-73.

${ }^{67} \mathrm{O}$ conceito de cidade liberal foi proposto pelo arquiteto Leonardo Benevolo, para dar conta do ambiente urbano que se formou durante a revolução industrial na Inglaterra e outros países europeus onde a política de laissez-faire teve uma expressão urbanística. BENEVOLO, Leonardo. Diseño de la ciudad. México: Gustavo Gili, 1979, pp.5-25. Nas tradições urbanas de Portugal e do Brasil, a cidade liberal nunca existiu oficialmente. As nossas cidades liberais reais são as favelas e bairros da lata, sempre encaradas como um mal a suprimir. 
${ }^{68}$ Sobre a cópia de posturas, ver um depoimento do século XVIII: OLIVEIRA, Extractos, pp.306-7. 